\title{
Первый черемисский словарь - архаический текст или конкорданс слов из нескольких марийских диалектов? (O. А. Сергеев. Василий Крекнин, Иоанн Платунов «Краткой черемиской словарь с российским переводом»: лингвистический анализ (с приложением словаря). Йошкар-Ола, 2020.348 с.)
}

Норманская Юлия Викторовна, Институт системного программирования им. В. П. Иванникова РАН; Институт языкознания РАН (Москва); julianor@mail.ru

\begin{abstract}
В рецензии исследуются отличия от литературного марийского языка, наблюдаемые в «Кратком черемиском словаре с российским переводом», с целью ответить на вопрос: был ли этот памятник составлен на пижанском говоре яранского диалекта северо-западного наречия марийского языка, на котором говорили в то время в Кукарской слободе, где был создан словарь, или, как утверждает О. А. Сергеев, «в “Кратком черемисском словаре с российским переводом” встречаются слова всех основных диалектов современного марийского языка» [Сергеев 2020: 17]? Для ответа на этот вопрос был проведен полный графикофонетический анализ словаря. Были выявлены три инновационные черты, свойственные яранском диалекту: ПМар. $* \dot{c}>u$,

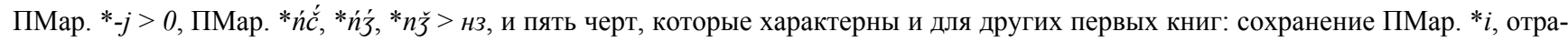
жение ПМар. * $\ddot{~ к а к ~} o$, ПМар. $w$ как $\sigma$, наличие сингармонизма. Единственной чертой, не отмеченной ни в книгах XIX в., ни в современных диалектах, является ПМар. ${ }^{*} \ddot{o}>$ e/э, которая может свидетельствовать о более позднем происхождении мар. $\ddot{o}<\Phi У * e$, чем считалось ранее. Таким образом, в рецензии показано, что словарь мог быть написан на пижанском говоре яранского диалекта, который в XVIII в. значительно отличался от современного состояния, в нем сохранились многие архаичные черты, свойственные и другим первым книгам. Анализ словаря позволяет уточнить историю яранского диалекта и время некоторых звуковых переходов.
\end{abstract}

Ключевые слова: марийские диалекты, хронология языковых изменений, первые книги, графика, фонетика

\author{
THE FIRST MARI DICTIONARY - AN ARCHAIC TEXT \\ OR CONCORDANCE OF THE WORDS FROM DIFFERENT MARI DIALECTS? \\ (O. A. SERGEEV. VASILIY KREKNIN, IOANN PLATUNOV \\ "A SHORT MARI DICTIONARY WITH RUSSIAN TRANSLATION": A LINGUISTIC ANALYSIS \\ (SUPPLIED WITH A DICTIONARY). YOSHKAR-OLA, 2020. 348 PAGES)
}

Julia V. Normanskaja, Ivannikov Institute for System Programming, RAS; Institute of Linguistics, RAS (Moscow); julianor@mail.ru

\begin{abstract}
This review analyzes the ways in which the Concise Cheremis-Russian Dictionary differs from the literary Mari language in order to answer the following question: was the dictionary compiled in the Pizhan subdialect of the Yaransk dialect of Northwestern Mari, which was spoken at that time in the Kukarskaya Sloboda, where the dictionary was created, or, as O. A. Sergeev claims, "words belonging to all the main dialects of the modern Mari language can be found in the Concise Cheremis-Russian Dictionary" [Сергеев 2020: 17]?

To answer this question, a comprehensive graphic-phonetic analysis of the dictionary has been carried out. Three innovative features inherent in the Yaransk dialect have been identified (PMari $*^{*}>u$, PMari $*_{-j}>0$, PMari $*^{\prime} \dot{c} \dot{c},{ }^{*} \dot{n} \zeta{ }^{*}{ }^{*} n \check{z}>n 3$ ) together with five more features that are characteristic of other first books: the preservation of the PMari $* i$, the reflection of PMari $* \ddot{o}$ as $o$ and PMari $* w$ as $b$, and the retention of vowel harmony. The only feature that occurs neither in the nineteenth-century books, nor in the modern dialects is the PMari $* \ddot{o}>e / \ni$, which may indicate a later origin of Mari $\ddot{o}<$ Finno-Ugric $* e$ than previously thought. Thus, the review shows that the dictionary could have been written in the Pizhan subdialect of the Yaransk dialect, which differed significantly from its modern state in the $18^{\text {th }}$ century as it retained many archaic features characteristic of other first books. The analysis of the dictionary allows one to refine the history of the Yaransk dialect and the dating of certain sound changes.
\end{abstract}

Keywords: Mari dialects, chronology of the dialect's changes, first books, graphics, phonetics

Работа выполнена при поддержке проекта РНФ № 20-18-00403 «Цифровое описание уральских языков на основе больших данных» (рук. Ю. В. Норманская). 
Этот текст написан как дополнение к рецензии Л. М. Ившина «Новая жизнь уникальной рукописи». Полностью поддерживая высокую оценку и признавая важность монографии О. А. Сергеева, которая дает возможность широкому кругу читателей познакомиться с рукописным марийско-русским словарем, созданным в 1785 г. В. Крекниным и И. Платуновым, в настоящей работе мы бы хотели остановиться лишь на одном аспекте книги - диалектной принадлежности словаря, которая, с учетом более широкого круга материалов XVIII-XIX в. по марийским диалектам, может быть определена иначе. Это представляется важным, поскольку, как показали исследования первых книг на чувашском [Савельев 2016], татарском [Нуриева 2015, 2017], башкирском [Норманская, Каримова, Экба 2017], казахском [Шаймердинова 2016; Дыбо, Норманская 2016], саамском [Бакула 2016; Норманская 2016], марийском [Ключева, Норманская 2015; Ключева 2017; Норманская 2017], удмуртском [Безенова 2016а, 2016б], мансийском [Норманская 2015a; Норманская, Кошелюк 2017], хантыйском [Moldanova, Normanskaja 2018], селькупском [Норманская 2015б] языках, рукописные памятники на уральских и тюркских языках достаточно точно отражают диалектные особенности XVIII-XIX в. О. А. Сергеев высказывает гипотезу о том, что «в "Кратком черемисском словаре с российским переводом" встречаются слова всех основных диалектов современного марийского языка... Проанализировав фонетические, лексические и морфологические особенности словаря, можно констатировать, что в рукописи в основном преобладают языковые материалы лугового, северо-западного и восточного наречий марийского языка» [Сергеев 2020: 17]. Ситуация, когда в одном памятнике: словаре, грамматике, богослужебной книге - были бы представлены без помет все основные говоры того или иного языка, нам ранее не встречалась. В большинстве случаев словари либо имеют указания на то, что слова собраны из разных языков или диалектов, либо основаны на материале одного говора, который часто отличается от современных диалектов, поскольку в нем может сохраняться архаический вид некоторых фонем или аффиксов, могут идти переходные процессы, когда для той или иной фонемы в тексте представлены как архаичные, так и инновационные рефлексы.

В рассматриваемом словаре на титульном листе указано место создания: «Краткой черемиской словарь с россійскимъ переводомъ собранный Кукарской слободы Троицкого собора протојереемъ Василіемъ Крекнинымъ и Спаской церкви діакономъ Јоанномъ Платуновымъ». Кукарская слобода в 1918 г. была переименована в пос. Советск, который с 1937 г. стал городом Советск Кировской области Российской Федерации. В этом районе марийцы говорят на северо-западном пижанском говоре марийского языка. По утверждению профессора Н. И. Исанбаева, словарь как раз отражает лексические особенности пижанского говора лугового наречия [Исанбаев 2014: 6].

Кто прав: Н. И. Исанбаев, который считает, что лексические особенности словаря соответствуют району, в котором он был создан, или О. А. Сергеев, который приводит различные слова, которые либо фонетически, либо лексически не отражают особенности пижанского говора, а указывают на то, что у словаря было много авторов из разных регионов?

\section{Есть ли доказательства участия носителей разных диалектов в составлении словаря?}

Для ответа на этот вопрос разберем аргументы О. А. Сергеева, опираясь не только на словари современных диалектов, но и на архивные материалы по марийским говорам, которые собрали между 1885-1943 гг. В. Поркка, А. Генетца, Ю. Вихманна, М. Рясянена, Т. Е. Уотила, Э. Итконена (их публикацию см. в [Моіsio, Saarinen 2008]). В этом словаре представлены материалы по следующим диалектам марийского языка:

— восточным: бирскому, калтасинскому, красноуфимскому, кильмезскому;

- луговым: моркинскому, сернурскому, волжскому, йошкар-олинскому;

- северо-западным: яранскому, козьмодемьянскому.

Очевидно, опора на более ранние лексические материалы важна, поскольку если в настоящее время то или иное слово представлено, например, только в моркинско-сернурском говоре, то, возможно, в XIX в., а тем более в XVIII в. это было не так.

Разберем ниже некоторые слова, которые О. А. Сергеев приводит в качестве аргументов в пользу участия в создании словаря носителей различных говоров, но которые в конце XIX — начале XX в. были широко представлены в большинстве марийских луговых говоров:

— «моркинско-сернурские», по мнению О. А. Сергеева, лексемы в словаре: тырма 'борона' < тат., по [Moisio, Saarinen 2008: 855], это слово было как в восточных, так и в луговых диалектах: Ob Okr $\mathrm{Mm}_{1}{ }^{1}$

1 Здесь и далее при сокращениях из словаря [Moisio, Saarinen 2008] подстрочные знаки обозначают разных информантов. 
$\mathrm{Mm}_{2} \mathrm{Mm}_{3}$ Oka Mmu Ms²; люнгалтэмъ 'качаю', по [Moisio, Saarinen 2008: 358], это слово было в восточных, луговых, северо-западных диалектах: Ob Okr $\mathrm{Mm}_{1} \mathrm{Mm}_{2}$ Ok Mmu Ms Mwo Mup NW $\mathrm{W}_{1}$; тугурь 'рубашка', по [Moisio, Saarinen 2008: 820], это слово было в восточных, луговых, северо-западных диалектах: $\mathrm{Ob}_{1}$ Oka K Ob 2 Okr Ok Ms Mm Mmu Mwo Mup W;

— «волжские», например: вита 'конюшня, сенной сарай' < чув., по [Moisio, Saarinen 2008: 68], это слово с гласным $i$ в первом слоге в соответствии с лит. $\ddot{y}$, что О. А. Сергеев считает признаком волжского диалекта, было в восточных, луговых диалектах: Oka, Ok, Mm 3 Mmu Mwo Mup;

— «уржумские», например: аникъ 'заворки', по [Moisio, Saarinen 2008: 12], это слово с гласным $i$ во втором слоге в соответствии с лит. $b l$, что О. А. Сергеев считает признаком уржумского диалекта, было в восточных, луговых диалектах: Ok, Mmu, Mup; винеранъ 'полотняный', по [Moisio, Saarinen 2008: 70], это слово с гласным $i$ в первом слоге в соответствии с лит. $b$ было в восточных, луговых диалектах: $\mathrm{Ob}_{2}$, Oka, Okr, Ok, Mwo;

— «восточные» марийские, например: олянъ 'тихий, тихо' < чув., по [Moisio, Saarinen 2008: 450], это слово было в восточных и луговых диалектах: $\mathrm{Ob}_{1}, \mathrm{Ms}, \mathrm{Mm}_{1}, \mathrm{Ob}_{2}$, Oka, Okr, Ok, Mwo.

Активное цоканье, которое, по мнению О. А. Сергеева, характерно именно для слов из йошкаролинского говора лугового наречия, например: иыкма 'тынина, тын', кужу шобецо 'полотенце', кюnцюкъ 'подушка', пакиа 'огород', пеике 'бочка', виашъ цонъ 'простосердечие', каце 'жених', иоклемъ 'в жертву приношу', тунемашь тоџьлио 'ученик' - также является диалектно-дифференцирующей чертой как для северо-западных, так и для горномарийских говоров.

Итак, из приведенного материала видно, что ни одна из перечисленных особенностей (ни фонетических, ни лексических) не является признаком только одного конкретного говора и не может служить доказательством того, что в составлении словаря участвовали носители разных диалектов. Более того, со временем фонетические и лексические особенности говоров значительно меняются, и то, что сейчас, по данным О. А. Сергеева, представлено только в одном определенном диалекте, 150 лет назад могло быть распространено на всей территории расселения марийцев.

\section{Возможно ли, что словарь был составлен только на пижанском говоре яранского диалекта северо-западного наречия марийского языка?}

Для ответа на этот вопрос следует провести полный фонетический, морфологический и лексический анализ. С точки зрения лексики, как указывается и в [Исанбаев 2014: 6], и в [Сергеев 2020: 18], говор словаря можно считать пижанским.

Ниже мы представим результаты фонетического и краткого морфологического анализа. Фонетический анализ выполнен нами на основе полной росписи всех отличий «Краткого черемисского словаря...» от литературного языка по изданию [Сергеев 2020]. Были выбраны все соответствия, которые представлены более чем в трех разных корнях, среди которых есть исконная лексика, и оценены с точки зрения их наличия в яранском диалекте. Ниже в п. I разобраны черты, которые свойственны яранскому диалекту, в п. II - те, которые в нем в настоящее время отсутствуют.

\section{I. Диалектные черты, которые свойственны яранскому диалекту}

I.1. пам. $\boldsymbol{u}$ - лит. $\boldsymbol{u}<$ ПМар. $* \boldsymbol{c}^{3}$

Вериенъ, верецъ 'для' - лит. верчын, верч

Гыщъ 'из' - лит. гыч

Имаџъ кушкамъ 1 спр. 'подрастаю’ - лит. йымач кушкам

Кюпиюкъ, кюнъ 1 скл. 'подушка' - лит. кӱпчык

Мериемъ 2 спр. 'чахну' - лит. мерчем

Онильы нескл. 'в третьем годе' - лит. ончылий

Оцьыни нареч. 'напрасно, вотще, тщетно' - лит. очыни

2 Здесь и далее указаны говоры, в которых данное слово было зафиксировано в аналогичном фонетическом виде в конце XIX — начале XX в., по [Moisio, Saarinen 2008].

${ }^{3}$ Примеры соответствия пам. $ч$ - лит. $ч$ связаны с рефлексами ПМар. *̌c, ср., например:

пючкушъ, шюнъ 1 скл. 'отрубок' - лит. пӥчкыши < ПМар. *püс k-;

пючкамъ 1 спр. 'отсекаю, вырезываю, перерубаю, прирезываю’- лит. пӥчкам < ПМар. *pück-.

В этом заключается фонетическое отличие памятника от современного яранского диалекта, в котором ПМар. *č совпадает с ПМар. ${ }^{*} \dot{c}>u$. 
Цакемъ 2 спр. 'подаюся назад, отступаю' - лит. чакем

Цамра, ранъ 'шар' - лит. чумыра

Виџкижъ 'тонкий, тонко' - лит. вичкыж < ПМар. *wı̌ck

Шјормыцъ, цонъ или шермещъ, ценъ 1 скл. 'оброт, узда' - лит. шӧрмыч < ПМар. *šว̈rməс́, *šrməс́ > JT š̈̈rmyc, JO šörmǘc.

$$
\begin{aligned}
& \text { I.2. пам. }-0 \text { - лит. }-\check{u}<\text { ПМар. }{ }^{*}-j \\
& \text { Мю 'мед’ - лит. мйй < ПМар. *тӥј > J тӥ } \\
& \text { Пи 'собака' - лит. пий < ПМар. * } p i j>\mathrm{J} p i \\
& T u \text { 'вошь' - лит. тий < ПМар. * } t i j>\mathrm{J} t i \text {. } \\
& \text { I.3. пам. нз - лит. нч < ПМар. *ń }
\end{aligned}
$$

Онзилъ 'первый, передний' - лит. ончыл < ПМар. *ońc̆́ > JT onзylny, JO anзylny

Регензе, зенъ 'мох' — лит. регенче < ПМар. *rсуә-ńa, -nз́ว

Ронземъ 2 спр. 'развертываю, развиваю' - лит. рончем

Шинзиме 'ведомый' - лит. шинчыме

Шиндза пунъ, нунъ 1 скл. 'ресница, бровь, вежди' - лит. шинчапун < ПМар. *šin-ža > JT šynza, JO šznzä

Койлянзикъ 'трудолюбивый, прилежный’ - лит. колянчык.

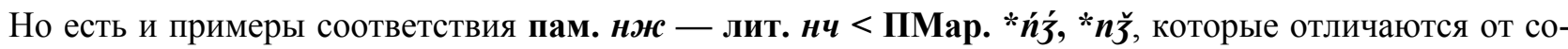
временного яранского диалекта:

Весъ онжошо, онъ 1 скл. 'иностранец' - лит. вес ончьшо

Иръ шинжсамъ 1 спр. 'сажусь в круг' - лит. йыр шинчам < ПМар. *šińźว- > JT šynzem, JO šənzem

Корно онжоктылше, шонъ 1 скл. 'вождь' - лит. корно ончыктышо

Кюнжемъ 2 спр. 'окопываю, копаю' - лит. кӥнчем < ПМар. *künз̌ə- > JT künzет, JO könзет.

Дважды отмечены слова, в которых к лит. нч приводятся слова с двумя типами соответствий пам. нз, нщ:

Јовунзе или јобунияо, нъ 1 скл. 'плащ, япанча' - лит. йовынчо

Вольгонцо или волгонзе, онъ 1 скл. 'молния' — лит. волгенче.

\section{II. Черты, которые не характерны для яранского диалекта, но могут быть архаичными или графическими приемами}

\section{II.1. Архаичные черты или графические приемы, которые встречаются в других марийских книгах}

II.1.1. пам. $u$ - лит. $b l<$ ПМар. $*_{i}$

Как было отмечено выше, такое соответствие встречается спорадически в некоторых словах как в XIX в., ср. винеранъ 'полотняный' $\mathrm{Ob}_{2}$, Oka, Okr, Ok, Mwo [Moisio, Saarinen 2008: 70], так и в современных диалектах, в первую очередь в шурминско-уржумском и малмыжском (особенно в кильмезском подговоре), более редко в бирском, йошкар-олинском и волжском говорах, см. подробнее [Ключева, Норманская 2015: 42-43]. Более часто аналогичная рефлексация представлена в доступных нам первых книгах как на луговом [Букварь 1873] ${ }^{4}$, так и на горном [Евангелие 1821] ${ }^{5}$ марийском языке. В [Евангелие 1821$] u$ является стандартным рефлексом для ПМар. ${ }^{*} i$ первого слога, хотя в современном горномарийском языке ПМар. ${ }^{*} i>$ ə. В [Букварь 1873] сохранение ПМар. ${ }^{*} i$ не является стандартным, но встречается достаточно часто. Таким образом, можно предполагать, что сохранение ПМар. ${ }^{*} i$ в части слов в «Кратком черемисском словаре...» отражает архаическую ситуацию, которая имела место до конца XIX в.

Килмемъ 2 спр. 'озябаю, замерзаю' - лит. кылмем

Килта, нъ 1 скл. 'сноп' - лит. кылта

Кине, нъ 1 скл. 'конопель' - лит. кыне

\footnotetext{
2015].

${ }^{4}$ Историю создания этой книги и обзор ее графических особенностей см. подробнее в [Ключева, Норманская

${ }^{5}$ Историю создания этой книги см. подробнее в [Эрцикова 2020].
} 
Киремъ 2 спр. ‘бью, бию’ - лит. кырем < ПМар. *kirz- > [Евангелие 1821] кир-я́шъ, кир-غ́нъ, кирغ́нулуть, кир-я́тъ, кири-не́шть

Киша, нъ 1 скл. 'след' - лит. кышиа

Нилить 'четыре' - лит. ныльыт < ПМар. *nil > [Евангелие 1821] ниль, [Букварь 1873] нил

Пидалме, менъ 1 скл. 'защита' - лит. пыдалме

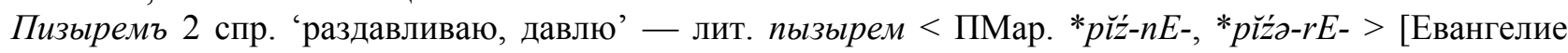
1821] пизир-не́же, [Букварь 1873] пизырен 'выжимая, выжав'

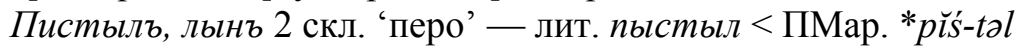

Сира или сра, ранъ 1 скл. 'пиво' - лит. сыра

Шибяга, ганъ 1 скл. 'жребий' — лит. щыввага

Шиже, жинь 1 скл. 'осень' - лит. шыюе < ПМар. *šižə > [Букварь 1870: 8] шижем / [Букварь 1873: 10] шыжем 'осенью'.

Но есть и более многочисленные случаи, когда пам. $\boldsymbol{b}$ - лит. $\boldsymbol{b}<$ СМар. * $\boldsymbol{i}$, ср. например:

Тылыззе, зенъ 1 скл. 'луна, месяц' — лит. тылзе > [Евангелие 1821] ти́льза

Тырмалемъ 2 спр. 'пашню бороню' - лит. тырмалем

Сырыше 'гневливый' — лит. сырыме

Пыль, лынъ 2 скл. 'облако' - лит. пыл < ПМар. *pil > пиль.

\section{II.1.2. пам. $u$ - лит. $\ddot{y}<$ ПМар. $*_{i}$}

Такое соответствие отмечено в [Bereczki 1994: 72-73], он указывает, что в ряде диалектов произошло развитие ПМар. $*_{i}>\ddot{u}$, которое он считает вторичным, возникшим уже после распада прамарийского единства, поскольку в ранних заимствованиях в татарский и чувашский представлены рефлексы $i$. В доступных нам первых книгах тоже есть примеры такого соответствия, ср. [Начатки христианского учения 1841]: шииштэ — лит. шӥштӧ 'кожа, кожаный', ширча̀ - лит. шӥрча 'жестокий’, ши́дарь — лит. шӥдыр 'звезда'. Аналогичное соответствие встречается и в материалах [Паллас 1787], ср. Идорь 'дева' лит. ӥбyr. Поэтому рефлекс, представленный в «Кратком черемисском словаре...», следует считать архаическим.

Имюръ, юнъ 'век' - лит. ̈̈мыр

Киваръ, ынъ 2 скл. 'мост' - лит. кёвар < чув.

Килтымашъ 'подлой, ни к чему не годной' — лит. кӱлдыммаш

Лигиштэль 2 спр. ‘сверблю' - лит. лӥгыштем

Пижсалтамъ 1 спр. 'потею' - лит. пӥжсалтам < ПМар. *piž, *pižaltam

Тиналмашъ, шынъ 2 скл. 'зачатие, начало, починание' - лит. тӱналам

Тинга, нъ 'строка' - лит. тӥн.

\section{II.1.3. пам. io/o - лит. $\ddot{o}<$ ПМар. * $\ddot{o}$}

Стандартной передачей ПМар. * $о$ в середине и в конце слова является диграф io/jo, сp.: кіоргишке тюнгюдэмъ 'вгибаю', піортыктенъ пужемъ 'раскатываю', піортше 'отмститель', тіорсыръ 'неравенство', шюргіо 'лицо', пјортоль онжеламъ 'оглядываюсь'. Но в «Кратком черемисском словаре....» в ряде случаев встречается передача через $o$, ср.:

тюко 'запор; также вещь' - лит. тӥкӧ

изи сосна 'свинка' - лит. изи сӧсна

люмо 'клей' — лит. лӥмӧ.

Аналогичные примеры есть и в [Евангелие 1821]: ко́ргоиъ - лит. кӧргыч 'изнутри', торЪ - лит. mӧр ‘прямо'; тора́ - лит. тӧра́ 'судья’. Вероятно, они свидетельствуют о недостаточно последовательной графической передаче звуков.

\section{II.1.4. пам. $\sigma$ - лит. $6<$ ПМар. ${ }^{*} w$}

В словаре [Bereczki 1992] такие рефлексы для ПМар. ${ }^{*} w$ отсутствуют, но по материалам конца XIX начала XX в., собранным в [Moisio, Saarinen 2008], они представлены во всех говорах. В [Паллас 1787: 11] также отмечена аналогичная рефлексация, ср. Абяй - лит. ава 'мать'. Вероятно, либо это был способ 
графической записи в XVIII-XIX вв., либо качество звука в то время во всех диалектах отличалось от современного.

Аба или $а в а, н ъ 1$ скл. 'мать, родительница' - лит. $а в a<$ чув.

Абанъ или аванъ 'матерний' - лит. аван

Аба кегерие, енъ 1 скл. 'голубка' - лит. ава кӧгӧрчен

Аза килимдэ пючше куба, нъ 1 скл. 'бабка повивальная’ — лит. аза кылымде пӱчшё кува

Арба, нъ 1 скл. 'мякина, плевы, кукол, волчец' - лит. арва

Иги шубо, унъ 1 скл. 'дети' - лит. икшыве

Обаргемъ 2 спр. 'надуваюся' - лит. оваргем

Рыбижъ, жинъ, рюбюжъ, жюнъ 1 скл. 'лисица' - лит. рывыж < ПМар. *riwəž

Лебедамъ 1 спр. 'одеваю, покрываю' - лит. леведам

Лебектемъ 2 спр. 'разогреваю' - лит. левыктем < ПМар. *lewə, *lewE-.

\section{II.1.5. Развитие гласных второго слога в зависимости от качества гласного первого слога}

Во всех доступных нам первых книгах, ср. [Паллас 1787; Евангелие 1821; Начатки христианского учения 1841; Букварь 1873], гласные второго слога более разнообразны, чем в литературном марийском: на месте лит. bl второго слога может встречаться большинство гласных. Правила их употребления часто зависят от качества гласного первого слога, но варьируются в разных книгах.

— Переход ПМар. *ə > $o, y, ю$ во втором слоге, если в первом слоге огубленный гласный $o, y, ю$ (сингармонизм)

Кодомо 'отставший' - лит. кодымо

Коктонать 'оба' - лит. коктынат - [Евангелие 1821] ко́ктуть

Колоштамъ 1 спр. 'слушаю' - лит. кольштам — [Евангелие 1821] колоштма́шъ

Колтомашъ, шынъ 2 спр. 'посылание' - лит. колтымаш

Кугужа, жанъ 1 скл. 'царь' - лит. кугыжа — [Евангелие 1821] кугужа̀

Кугуза или кугузя, зянъ 1 скл. 'старик' - лит. кугыза

Олокъ, конъ 1 скл. 'луг' - лит. ольюк < чув.

Онгоръ, ронъ 1 скл. 'колокольчик' - лит. онгыр

Удуремъ 2 спр. 'гребу' - лит. удырем

Ультумашъ, шынъ 2 скл. 'моление' - лит. улдыммаш

Умулча, чанъ 1 скл. 'камыш трава' - лит. умылча

Мушкундо, дунъ 1 скл. ‘кулак’ — лит. мушкындо < ПМар. *muškəndə

Шюбюль, бюлюнь 1 скл. 'слюна' - лит. шӥвыл.

Отметим, что в «Кратком черемисском словаре...» сингармонизм не является регулярным. Значительное количество примеров с $o, y$ в первом слоге имеют $u, b l$ во втором слоге, ср., например:

Онжике нареч. 'впредь' - лит. ончыко

Онзиль 'первый, передний' — лит. ончыл

Онзыке пуремъ 2 спр. 'предъускоряю, предъупреждаю' — лит. ончыко пурем.

— Переход ПМар. *ə > e, э при $a, \ddot{o}$ в первом слоге:

Аремешъ пуемъ 2 спр. ‘даю в рост, в процент даю’ - лит. арымеш пуэм

Ашнеме эрге, енъ 1 скл. 'вскормленик' - лит. ашныме эрге

Ватэдъманъ, ынъ 2 скл. 'безженный, вдовец' — лит. ватыдыман, ватыдыме

Ватэ ятеръ јянъ, ынъ 2 скл. 'жена довольных лет' - лит. вате ятыр иян (иям)

Жаплэме 'почтенный' - лит. жаплыме

Палемъ пуемъ 2 спр. 'знак даю' - лит. палым пуэм

Эрдежълу, лунъ 1 скл. 'ребро’ - лит. ӧрдыжлу< ПМар. *ӧrбə-ž.

Аналогичная гласная во втором слоге после $a$ в первом наблюдается в материалах П. С. Палласа, ср. Азренъ 'смерть' [Паллас 1787: 222] - лит. azyrén. В [Евангелие 1821; Букварь 1873] в словах с $a$ в первом слоге в соответствии с лит. bl второго слога употребляется $a$, ср.: ámaмb - лит. ámbым 'сосуд' [Евангелие 1821], вятажа - литер. ватыже [Букварь 1873: 14] '(его) жена'. 


\section{II.2. Архаичная черта, которая отсутствует в других марийских диалектах и доступных нам первых книгах:}

пам. $e / \ni$ — лит. $\ddot{o}<$ ПМар. * $\ddot{o}$

Кегерие, нъ 1 скл. 'голубь' - лит. кӧгӧрчен

Неремъ 2 спр. 'мокну' - лит. нӧрем

Нэрепъ, пенъ 1 скл. 'погреб' - лит. нӧреп < чув.

Пелекымъ пуэдэмъ 2 спр. 'раздариваю, дарю' - лит. пӧлекым пуэдем

Пелякъ налше 'одаренный' - лит. пӧлек налше

Пютэ 'пост' - лит. пӱтӧ

Сербалемъ 2 спр. 'прошу, упрашиваю, умоляю' - лит. сӧрвалем

Тэрлальтемъ 2 спр. 'сравниваю, выравниваю' - лит. тӧрлалтем

Тэрыштемъ 2 спр. 'выскакиваю' - лит. тӧрштем

Тэръ веръ, ренъ 1 скл. 'площадь' - лит. тӧр вер

Тюке 'различие' - лит. тӥкӧ

Шеренъ мутланемъ 2 спр. 'отговариваю' - лит. шӧрен мутланем

Шурно ерза, занъ 1 скл. 'хлебной короб' - лит. шурно ӧрза

Шюле 'овес' — лит. шӥльё

Элталэмъ 2 спр. 'обнимаю’ - лит. ӧндалам

Эпкелемъ 2 спр. 'выговариваю' - лит. ӧпкелем

Эрамъ 1 спр. 'изумляюся, дивлюся' - лит. ӧрам

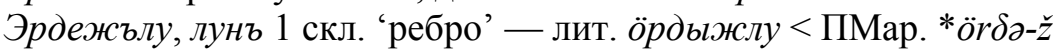

Эрканыдеме 'не ленивый’ - лит. ӧрканыдыме

Эрмашъ, шынъ 2 скл. 'чудо' - лит. ӧрмаш.

В начале слова ПМар. * $о ̈$ всегда передается как э/е, в ряде случаев такая рефлексация зафиксирована в середине и в конце слова, при этом стандартной передачей является io/jo/o, совпадающее с другими первыми книгами. Объяснить переход ПМар. * $\ddot{o}>$ э/e, который не представлен ни в современных диалектах, ни в доступных нам первых книгах, довольно сложно. Стоит обратить внимание, что по [Bereczki 1994: 116-117] ПМар. * $\ddot{o}<\Phi У ~ * e,{ }^{*}$; такое развитие происходило в большинстве случаев в позиции перед $-r$. Отметим, что и в примерах из «Краткого черемисского словаря...» соответствие лит. * $\ddot{o}$ - пам. э/е достаточно часто встречается именно в позиции перед - $p$. Возможно ли, что в «Кратком черемисском словаре...» отражен еще ФУ гласный *e, а переход в * $̈$ был более поздним? Косвенное подтверждение этой гипотезы можно найти в Рукописном русско-марийском словаре середины XVIII в., найденном в архиве Г. Ф. Миллера, см. подробнее [Исанбаев 2000], где встречается соответствие пам. $u$ - лит. $\ddot{o}$, например, ирдизень 'на боку' - лит. ӧрдыж.

Полный морфологический анализ «Краткого черемисского словаря...» - дело будущего, поскольку морфонологическая форма аффиксов еще недостаточно, с нашей точки зрения, изучена ни в современных диалектах, ни в первых книгах. Остановимся лишь на наиболее значимом с точки зрения диалектной классификации признаке: форме показателя множественного числа.

В «Кратком черемисском словаре...», как указано в [Сергеев 2020: 75], в качестве показателя множественного числа употребляется суффикс -шамыц, обнаруженный в 18 словарных статьях, например: ирангъ-шамыцымъ лиштемъ 'борозды делаю', јигирь шамыцъ 'ежегодный', кіаматыште илишешамыцъ 'адские жители', кіоргысе ужаш шамыцъ 'внутренние части', кугезе шамыцъъ 'предки', межашъ шамыцемъ лиштэмъ 'рубежи ставлю', пютюрме юпшамыцъ 'завитые волосы', родо шамыцымъ поминаемъ 'родителей поминаю', саръ јень шамыцъ 'армия, военный народ', цонъ шамещъ колошонъ 'души умерших', шочшошамецъ 'потомки', юмбащъ пиштыме юпь-шамыщъ 'волосы накладные', юмушто илишешамецъ 'небесные жители'.

Отсутствие в «Кратком черемисском словаре...» показателей -влӓ, -влак, -лак, -шамыц, которые могли бы указывать на горномарийский (-влӓ), луговой марийский ${ }^{6}$ (-шамыч, -влак), восточный марийский (-влак, -лак), доказывает, что словарь написан либо на северо-западном наречии, либо на йошкаролинском говоре, см. подробнее [Bereczki 1994: 19-27]. С учетом того, что словарь, как было сказано выше, создан в Кукарской слободе, где живут носители пижанского говора северо-западного наречия, форма наиболее значимого морфологического показателя также не противоречит гипотезе о создании словаря на основе одного говора.

\footnotetext{
6 За исключением йошкар-олинского говора.
} 
Отметим также, что в рукописи «Краткого черемисского словаря...», первые страницы которой опубликованы в [Сергеев 2020], присутствуют знаки ударения, которое отличается и от литературного лугового языка, и от горного, ср. асу́ръ 'пучина'. К сожалению, в издании словаря знаки ударения опущены, поэтому нет возможности сделать полное описание его акцентуации без обращения к тексту рукописи. Предположительно, в словаре представлена и архаическая система ударения, описание которой дело будущего.

\section{Вывод}

Итак, проведенный анализ показывает, что по итогам лексического, фонетического, морфологического анализа «Краткого черемисского словаря...» создание его только на основе пижанского говора яранского диалекта северо-западного наречия представляется наиболее вероятным. Все отличия языка словаря от современного яранского диалекта являются либо архаизмами, которые совпадают с праязыковыми формами, представленными не только в этом словаре, но и в других первых книгах, созданных в разных регионах, а также в некоторых современных диалектах, либо графическими особенностями и приемами, которые были типичны и для других первыX книг XVIII-XIX вв.

Этот результат позволяет нам понять важность «Краткого черемисского словаря...» для истории марийского языка и, в частности, северо-западного наречия, которое не имеет письменности и является менее изученным. Анализ графико-фонетических особенностей словаря показывает, что двумя четкими инновационными чертами яранского диалекта северо-западного наречия того времени были переходы ПМар. ${ }^{*} \dot{c}>c, *_{-j}>0$. Остальные инновационные процессы: ПМар. ${ }^{*} \dot{n} \dot{c},{ }^{*} n^{\prime} \dot{z},{ }^{*} n \check{z}>n z$, переход в первом слоге ПМар. $*_{i}>\dot{i}, \ddot{u}$, переход гласных второго слога в $\dot{i},-$ только начались, поэтому есть как примеры, в которых они отражены, так и те, где сохранились архаические прамарийские рефлексы. В то время еще не было перехода ПМар. ${ }^{*} \check{c}>c$, характерного для современного яранского диалекта. Видимо, сохранялась архаичная система акцентуации. Материалы Ю. Вихманна по яранскому диалекту, собранные в 1906 г. и опубликованные в [Moisio, Saarinen 2008], и Э. Беке, также записанные в самом начале XX в. и изданные в 9-томном словаре [Beke 1997-2001], показывают, что за последующие 120-130 лет большинство инновационных процессов, упомянутых выше, завершились.

\section{Сокращения}

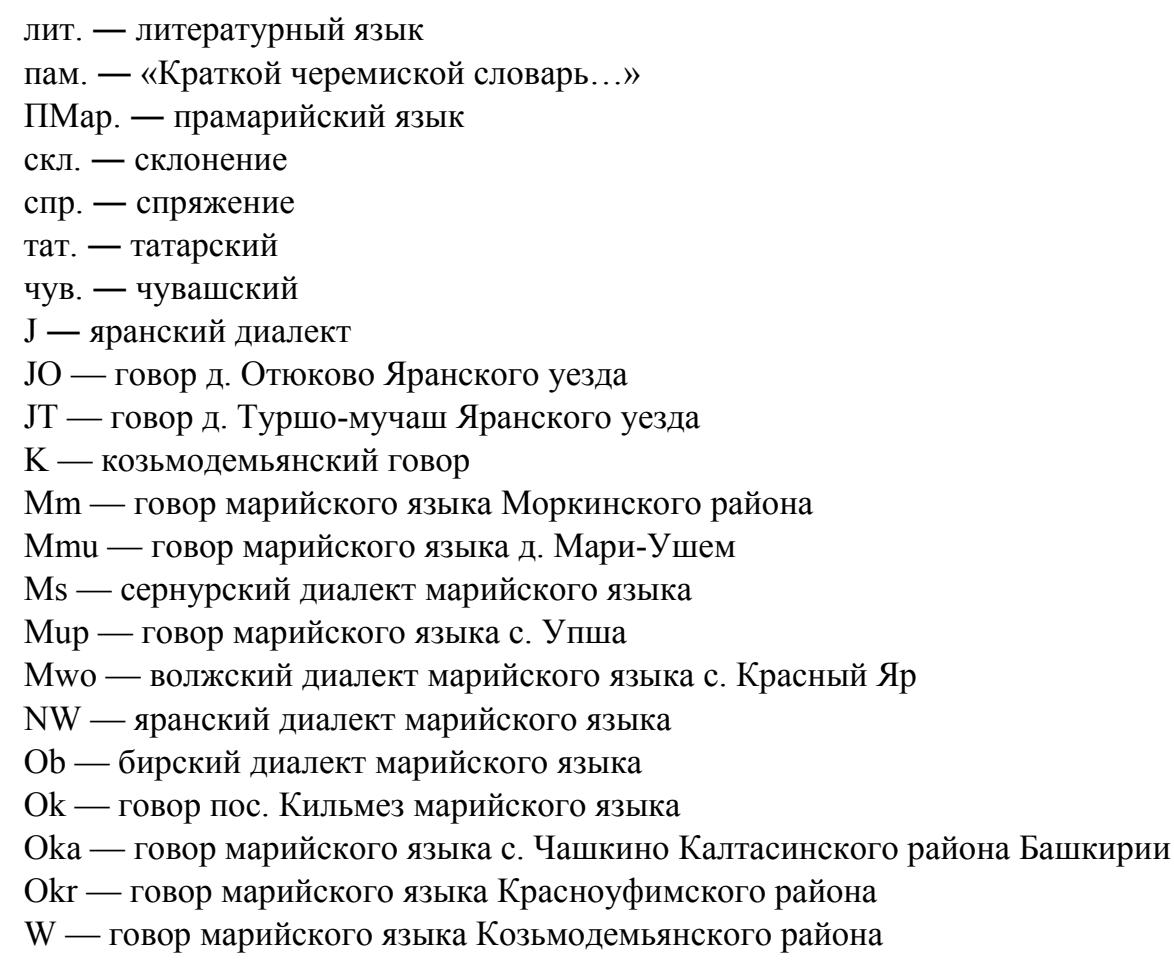




\section{Литература}

Бакула 2016 - Бакула В. Б. Вокализм первого слога в кильдинском диалекте саамского языка по данным Евангелия от Матфея (1878) // Урало-алтайские исследования. 2016, 3 (22). С. 13-33. \{Bakula V. B. Vocalism of the first syllable in the Kildin Sami dialect (case study of Matthew 1878) // Ural-Altaic Studies. 2016, 3 (22). P. 13-33.\}

Безенова 2016а - Безенова М. П. Наставление христианское святителя Тихона на вотском языке 1891 г.: графические и вокалические особенности // Урало-алтайские исследования. 2016, 1 (20). С. 7-40. \{Bezenova M. P. Тhe Udmurt written monument "Christian admonition of Saint Tikhon in the Votyak language" of 1891: graphic and vocalic features // Ural-Altaic Studies. 2016, 1 (20). P. 7-40.\}

Безенова 20166 - Безенова М. П. Наставление христианское святителя Тихона на вотском языке 1891 г.: особенности консонантизма // Урало-алтайские исследования. 2016, 3 (22). С. 46-63. \{Bezenova M. P. The Udmurt written monument "Christian admonition of Saint Tikhon in the Votyak language" of 1891: consonant features // UralAltaic Studies. 2016, 3 (22). P. 46-63.\}

Букварь 1870 - Упрощенный способ обучения чтению черемисских детей лугового населения. Казань, 1870. [РНБ ЭК] \{The simple way to teach reading for Meadow Mari. Kazan, 1870. [RNB EK]\}

Букварь 1873 - Букварь для луговых черемис. Казань, 1873. [РНБ ЭК] \{АВС book for Meadow Mari. Kazan, 1873. [RNB EK]\}

Дыбо, Норманская 2016 - Дыбо А. В., Норманская Ю. В. Первые кириллические книги на казахском языке как источники для изучения диалектов // Урало-алтайские исследования. 2016, 4 (23). С. 139-153. \{Dybo A. V., Normanskaya $Y u$. $V$. The first Cyrillic books in Kazakh as a base for studying the history of dialects and creating a literary standard // Ural-Altaic Studies. 2016, 4 (23). P. 139-153.\}

Евангелие 1821 - Иисусъ Христосанъ святой Ейангелья Матөей-гыцъ, Марко-гыцъ, Лука-гыцъ Іоаннъ гыцатъ. Питеръ: Ладъ доно сирмяшъ ишташь Н. Гречь заводъ, 1821. \{The Fourth Gospel. Saint-Petersburg, 1821.\}

Исанбаев 2000 - Исанбаев Н. И. Рукописный русско-марийский словарь середины XVIII века // Марийский археографический вестник. 2000, 10. С. 201-214. Электронный доступ: http://www.vostlit.info/Texts/Dokumenty/ Russ/XVIII/1740-1760/Russ mari slovar/text.htm. \{Handwritten Russian-Mari dictionary of the middle of the $18^{\text {th }}$ century // Mari Archeographic Bulletin. 2000, 10. P. 201-214. On-line: http://www.vostlit.info/Texts/Dokumenty/Russ/XVIII/ 1740-1760/Russ mari slovar/text.htm.

Исанбаев 2014 - Исанбаев Н. И. Русские лексические заимствования дооктябрьского периода в марийском языке: Словарь-справочник. Йошкар-Ола, 2014. \{Isanbaev N. I. Russian loanwords of the pre-revolutionary period in Mari language. Yoshkar-Ola, 2014.\}

Ключева 2017 - Ключева М. А. Первые марийские буквари (лугового наречия) 1870-х гг. Ч. 2. Особенности консонантизма // Урало-алтайские исследования. 2017, 4 (27). С. 113-138. \{Klyucheva M. A. The first Mari alphabet books of the meadow dialect (1870s): Part II. Features of Consonantism // Ural-Altaic Studies. 2017, 4 (27). P. 113-138.\}

Ключева, Норманская 2015 - Ключева М. А., Норманская Ю. В. Первые луговомарийские буквари 1870-х гг.: лингвистический обзор. Часть І. Введение. Гласные звуки и буквы для них. Урало-алтайские исследования. 2015, 3 (18). C. 18-63. \{Klyucheva M. A., Normanskaya Yu. V. The first Meadow Mari alphabet books (1870s): a linguistic review. Part I. Introduction. Vowels and letters for them. Ural-Altaic Studies. 2015, 3 (18). P. 18 -63.\}

Начатки христианского учения 1841 - Начатки христианского учения, или Краткая Священная история и Краткий катехизис, на черемисский язык лугового наречия переведенные в Казани 1839 года. Казань, 1841. \{Ваsic Christian doctrine, or a Short Sacred History and a Short Catechism, translated into the Meadow Mari language, translated in Kazan in 1839. Kazan, 1841.\}

Норманская 2015а - Норманская Ю. В. Новые полевые и архивные данные по мансийским диалектам и их значение для прамансийской реконструкции системы вокализма первого слога // Урало-алтайские исследования. 2015, 4 (19). C. 63-78. \{Normanskaya Yu. V. New field and archival data on Mansi dialects and their significance for the reconstruction of the Proto-Mansi system of the first-syllable vocalism. Ural-Altaic Studies. 2015, 4 (19). P. 63-78.\}

Норманская 20156 - Норманская Ю. В. Ударение в первых книгах на селькупском языке, созданных Н. П. Григоровским в XIX веке // Томский журнал лингвистических и антропологических исследований. 2015 , 4. С. 9-17. \{Normanskaja Yu. V. Accent in the first Selkup books, created by N. P. Grigorovsky in the $19^{\text {th }}$ century // Tomsk Journal of Linguistics and Anthropology. 2015, 4. P. 9-17.\}

Норманская 2016 - Норманская Ю. В. Евангелие от Матфея 1878 как памятник точной фиксации архаического состояния кильдинского диалекта // Урало-алтайские исследования. 2016, 3 (22). С. 34—45. \{Normanskaya Yu. V. 1878 Gospel according to Matthew as a precise fixation monument of the Kildin dialect in archaic state // Ural-Altaic Studies. 2016, 3 (22). P. $34-45$.

Норманская 2017 - Норманская Ю. В. Дискуссионная заметка к статье М. А. Ключевой «Первые марийские буквари (лугового наречия) 1870-х гг. Ч. 2. Особенности консонантизма» // Урало-алтайские исследования. 2017, 4 (27). C. 138-144. \{Normanskaya Yu. V. A polemic note to the article "The first Mari alphabet books of the meadow dialect (1870s): Part II. Features of Consonantism” by Maria Klyucheva // Ural-Altaic Studies. 2017, 4 (27). P. 138—144.\} 
Норманская, Каримова, Экба 2017 - Норманская Ю. В., Каримова Р. Н., Экба 3. Н. В. В. Катаринский — автор первой кириллической книги на башкирском языке? // Урало-алтайские исследования. 2017, 2 (25). С. 46-53. \{Normanskaya Yu. V., Karimova R. N., Ekba Z. N. Is V. V. Katarinski the author of the first Bashkir-language book? // Ural-Altaic Studies. 2017, 2 (25). P. 46-53.\}

Норманская, Кошелюк 2017 - Норманская Ю. В., Кошелюк Н. А. Архивный пелымско-русский словарь, составленный русским священником о. Константином Словцовым, как источник, позволяющий оценить точность записей в мансийских словарях А. Каннисто и Б. Мункачи // Урало-алтайские исследования. 2017, 3 (26). С. 151161. \{Normanskaya Yu. V., Koshelyuk N. A. Archival Pelym-Russian dictionary, compiled by the Russian priest, father Konstantin Slovtsov, as a source for estimating the accuracy of recordings in the Mansi dictionaries of A. Kannisto and B. Munkácsi // Ural-Altaic Studies. 2017, 3 (26). P. 151-161.\}

Нуриева 2015 - Нуриева Ф. Ш. Диалектная основа книг на «крещено-татарском» языке второй половины XIX века // Урало-алтайские исследования. 2015, 2 (17). С. 67-74. \{Nurieva F. Sh. The dialectal base of the books written in "christened Tatar" in the latter half of the $19^{\text {th }}$ century // Ural-Altaic studies. 2015, 2 (17). P. 67-74.\}

Нуриева 2017 - Нуриева Ф. Ш. Языковой памятник говора сергачских мишарей: текст исповеди XIX века // Урало-алтайские исследования. 2017, 3 (26). С. 161-174. \{Nurieva F. Sh. A linguistic monument of the Sergach Mishars' dialect: a confession text from the $19^{\text {th }}$ century // Ural-Altaic Studies. 2017, 3 (26). P. 161-174.\}

Паллас 1787 - Паллас П. С. Сравнительные словари всех языков и наречий, собранные десницею всевысочайшей особы. Отделение 1 , ч. 1: Отделение 1 , содержащее в себе европейские и азиатские языки. СПб., 1787. \{Pallas P. S. Comparative dictionary of all languages and dialects. Section 1, part 1. Saint-Petersburg, 1787.\}

Савельев 2016 - Савельев A. В. Чувашский перевод одной проповеди середины XIX века // Урало-алтайские исследования. 2016, 1 (20). С. 68-105. \{Savelyev A. V. The Chuvash translation of one sermon of the mid-19 ${ }^{\text {th }}$ century $/ /$ Ural-Altaic Studies. 2016, 1 (20). P. 68-105.\}

Сергеев 2020 - Сергеев О. А. Василий Крекнин, Иоанн Платунов «Краткой черемиской словарь с российским переводом»: лингвистический анализ (с приложением словаря). Йошкар-Ола, 2020. \{Sergeev O. A. Vasiliy Kreknin, Ioann Platunov "A short Mari dictionary with Russian translation": a linguistic analysis (supplied with a dictionary). Yoshkar-Ola, 2020.\}

Шаймердинова 2016 - Шаймердинова Н. Г. Анализ системы консонантизма в казахских памятниках конца XIX - начала XX вв. // Урало-алтайские исследования. 2016, 4 (23). С. 128-138. \{Shaymerdinova N. G. Analysis of the consonant system in the Kazakh written monuments of late $19^{\text {th }}$ and early $20^{\text {th }}$ centuries // Ural-Altaic Studies. 2016, 4 (23). P. $128-138$.

Эрцикова 2020 - Эрциикова Г. А. Графико-орфографические особенности Евангелия 1821 года на марийском (горном) // Ежегодник финно-угорских исследований. 2020. Том 14. № 1. С. 6-13. \{Ertsikova G. A. Graphic and spelling features of the Gospel of 1821 in the Hill Mari language // Yearbook of Finno-Ugric Studies. 2020. Vol. 14. № 1. P. 6-13.\}

Beke 1997-2001 — Beke Ö. Mari nyelvjárási szótár 1-9. Unter Mitarbeit von Zsófia M. Velenyák und József Erdődi, neu redigiert von Gábor Bereczki, bearbeitet von Margarita Kuznecova, herausgegeben von János Pusztay (Bibliotheca Ceremissica 4). Szombathely, 1997-2001.

Bereczki 1992 - Bereczki G. Grundzüge der tscheremissischen Sprachgeschichte II (Studia Uralo-Altaica 34). Szeged, 1992.

Bereczki 1994 - Bereczki G. Grundzüge der tscheremissischen Sprachgeschichte I (Studia Uralo-Altaica 35). Szeged, 1994.

Moisio, Saarinen 2008 - Moisio A., Saarinen S. Tscheremissisches Wörterbuch ausgezeichnet von Volmari Porkka, Arvid Genetz, Yrjö Wichmann, Martti Räsänen, T. E. Uotila und Erkki Itkonen. Helsinki, 2008.

Moldanova, Normanskaja 2018 - Moldanova I., Normanskaja Ju. The Graphical Features of the first texts in the Khanty language $/ /$ The $5^{\text {th }}$ International Multidisciplinary Scientific Conference on Social Sciences and Arts SGEM 2018. Vol. 5. 3.1. P. 197-204. 